\author{
Professor Georgeta VINTILĂ, PhD \\ E-mail: georgeta.vintila@fin.ase.ro \\ Faculty of Finance and Banking, Department of Finance \\ The Bucharest University of Economic Studies \\ Associate Professor Ștefan Cristian GHERGHINA, PhD Habil \\ E-mail: stefan.gherghina@ fin.ase.ro \\ Faculty of Finance and Banking, Department of Finance \\ The Bucharest University of Economic Studies \\ Cosmina Ştefania CHIRICU, PhD Candidate \\ E-mail: cosmina.stefania@ymail.com \\ Doctoral School of Finance \\ The Bucharest University of Economic Studies
}

\title{
DOES FISCAL POLICY INFLUENCE THE ECONOMIC GROWTH? EVIDENCE FROM OECD COUNTRIES
}

\begin{abstract}
This study highlights the effects of the fiscal and economic factors as well as of the worldwide governance indicators on the economic growth rate in the OECD countries for a period of time between 2002 and 2017. The empirical analysis implies the use of a Panel data which is econometrically estimated by applying the "least squares method" and the "generalized method of moments", as we reasoned it would improve the efficiency of the estimation and remove the discrepancies caused by weak factors. The evidence shown positive links between the fiscal factors and economic growth as a result of the implementation of efficient and expansionary fiscal policies in the OECD countries. On a large scale, the worldwide governance indicators have proven to have positive effects on economic growth, but the government expenditure is the only economic variable of control which has negative impact on the economic growth. The conclusions bring forth the importance of the study by emphasizing on the future fiscal policies and strategies that should be considered by parties in order to stimulate the economic growth and to apply fair taxes.
\end{abstract}

Keywords: taxation, economic growth, worldwide governance indicators, OECD countries, panel data, generalized method of moments

JEL Classification: H29, H24

\section{Introduction}

The Organization for Economic Cooperation and Development (hereinafter OECD), was established in the year 1948 with the purpose of developing and reconstructing Europe after the Second World War. As of the year 2020, the organization comprises 37 of the most well-economically developed states of the world. This paper is based on the econometric analysis of the impact of taxation on 
the economic growth in 36 OECD Member States, having as a reasoning the research of the influences rendered by the following variables: structure of the fiscal systems of the member countries, the gross domestic product amount, the rate of economic growth, economic stability, foreign trade, investment and cooperation towards development.

Moreover, we propose through this analysis to quantify the impact of taxation on the income of the taxpayers and to also highlight its influences on the workforce (Decoster et al, 2010). Furthermore, we considered necessary to include in our assessment the years related to the economic crisis, respectively 2007-2010 and, compared to previous studies performed by other authors (Mdanat et al, 2018, Munir and Sultan, 2018) we comprised in our analysis a large number of countries. For the purpose of the clear estimation of the models, the following methods are used: "the least squares method" with application of fixed and random effects and the "generalized method of moments" as also considered in the reference papers (Armeanu et al, 2018).

On the other hand, we noticed that the fiscal policies practiced amongst OECD countries are likely to disadvantage certain social groups which do not have political and economic decision-making authority and thus the latter are excluded from political debates and their decisions are ignored. Such groups are represented by poor citizens and women. Therefore, in order to quantify the influences of these disadvantageous tendencies on the economic growth and since the results of other authors on this subject do not have significant magnitude on the reference literature (Haggard and Tiede, 2011, Mdanat et al, 2018) we introduced as variables the public governance indicators. Also, this study emphasizes on the relationship between the fiscal policy and economic growth as a result of the fact that taxes are the main resources controlled by governments through the fiscal policy of the respective country and are the main issue of the endless political debates. In fact, the resolution of democratic countries is highly dependent on the ability of the political parties and interest groups to influence political decisions and citizens so that these policies would reduce poverty and increase the welfare of the society (Arin and Koray, 2006, Arnold et al, 2011, Gemmell et al, 2011, Lucas, 1988).

Moreover, we determined that public spending exerts negative influence on economic growth, which is in accordance with the results presented in previous studies (Jones et al., 1993, Barro, 1990). Such negative impact is highlighted by non-productive expenses that could not encourage investments and could not help lowering the unemployment rate. Also, governments collect taxes in order to fulfil their duties to society and to finance government spending. The activities of the authorities to receive and incur public revenues and expenditures are a topic of great interest for researchers (Wang et al, 2014, Carboni, 2017,) because these variables have significant effect on the economic growth rate. Thus, public expenditure is performed in order to meet the collective needs of citizens and to stimulate economic and social well-being. Alongside, social assistance measures aim to help the poor population when public spending is incurred effectively by

DOI: 10.24818/18423264/55.2.21.14 
Does Fiscal Policy Influence the Economic Growth? - Evidence from OECD Countries

financing national security and protecting citizens by ensuring a quality educational system and maintaining a high standard health system.

Taxes are the most important fiscal resource and have the largest share in public revenues. Depending on the taxpayer, the type of taxes is either direct or indirect, with the latter representing a reliant way of increasing public revenues which guarantees the governments an efficient management of its fiscal policies since the final consumer is the person who bears the tax burden. Indirect taxation constitutes an advantageous solution towards externalities (Helbling, 2010) mainly because of the fact that increasing indirect taxation implies the rising of prices followed by a reduction in consumption and also a lessening of the negative effects caused by the defective management of governments in applying fiscal policies. To add to these, indirect taxation rates and legal provisions are difficult to amend between fiscal periods without a previous acceptance of the Parliament.

In conclusion, in order to highlight the impact of fiscal policies on economic growth we settled up the empirical study on the analysis of public governance indicators, fiscal and economic variables for OECD countries for a period of time between 2002 and 2017. The first part of this paper comprises a review of the reference literature followed by the presentation of the methodology, the variables and database used together with the results and conclusions emerged from the estimation of the models.

\section{Literature Review}

In the reference literature (Arin and Koray, 2006, Arnold et al, 2011, Arnold, 2008) it is stated that taxes, regardless of their nature, have both positive and negative impact on growth which manifests at macroeconomic and microeconomic level. If for example the level of taxation in a state is high, the taxpayer's ability to work decreases considerably and he may become hesitant to work more because by increasing taxation his income would become considerably reduced. Also, an increased level of taxation has negative effects on the income distribution and it indirectly alters the productive capacity. Moreover, taxation affects the allocation of production and the income of the population, fact that leads to significant consequences on the social welfare; in this regard it is therefore recommended for governments to also consider the economic and social impact of taxation, especially because increasing the level of taxation will cause taxpayers to work harder in order to maintain balanced their income levels but it will worsen their financial situation. Furthermore, it is considered that economic resources could be supplied in capital investments through savings, although the saving rate could affect the level of the economic activities by influencing the aggregate demand. Decoster et al. (2010) argue that the major disadvantage of indirect taxation is the considerable burden for people with high levels of consumption while indirect taxation is unfair because the average tax rate is higher for the

DOI: 10.24818/18423264/55.2.21.14 
citizens with low income as they have to pay a high amount of their income for consumption.

Ekins et al. (2012) debates the problem of externalities, which are of great interest for the study of political economy because externalities have indirect effects upon consumption or production activities that were undertaken by certain economic agents upon other economic agents such as companies or citizens. Helbling (2010) considers that the impact of externalities is to create in the competitive market a shortage of goods and services demanded by consumers because of the manner in which another economic agent affected the business environment. The author concludes that it is important to highlight the fact that increasing the indirect tax rates would lead to higher prices, but it would discourage consumption and reduce the effects of negative externalities such as environmental disasters. An important argument against indirect taxation is that indirect taxes tend to become regressive because each citizen, no matter the income level, pays the same share for what buys, leaving the poorer to pay indirect taxes in a higher proportion of his own income than one with higher income (Decoster et al., 2010). On the other hand, the main arguments in the application of governmental expenditure are: i) it provides citizens' safety against external aggressive factors, internal disorder and injustice, as a reason that public authorities are working in different manners in order to provide social welfare; ii) encourage social development and growth of communities because through public spending, governments could influence directly and indirectly the industrial and commercial systems around the states which provides social welfare. Moreover, governmental expenditure implies the optimization of direct investments so that it could help reduce unemployment rate. Meantime, regardless of whether a country is well developed or still developing, governments may impose taxes in order to fund the public expenses incurred. Although many developing countries are dependent on external aid, taxes are the main source of public income. Other own resources of a developing country consist of revenues resulted from the application of tariffs, licenses, mineral or oil royalties.

The interest in analyzing the correlation between the fiscal policy and economic growth in the developing countries has advanced in recent years with the recognition of the necessity to stimulate the rate of economic growth and to reduce the budget deficits that arise as a result of inefficient government spending. For an economic growth rate to be sustainable and efficient, economists (Arnold et al., 2011, Gemmell et al., 2011) argue that policies need to be adjusted towards reducing the poverty and inequalities of chances for the welfare of society. Moreover, fiscal policies can affect economic growth through several factors such as the unemployment rate, total human capital productivity and rising the financing costs. Fiscal policies such as increasing the public spending on healthcare and education on one hand and reducing tax rates on the other hand can positively influence the stock of human capital and support economic growth. However, the reference literature regarding the impact of taxation on economic growth is a

DOI: 10.24818/18423264/55.2.21.14 
Does Fiscal Policy Influence the Economic Growth? - Evidence from OECD Countries

controversial aspect of the economy because the decisions taken by certain individuals and institutions have consequences and direct impact on the general economy. Armeanu et al. (2018) conclude an empirical study on the sustainability factors of economic growth rate in the EU-28 member countries by using data panel regression models and by applying fixed and random effects and the generalized method of moments. The sustainability factors of the real growth rate of the gross domestic product include the high level of education, the economic and business environment of a country, technology, infrastructure, communications, people's lifestyle, media and demographic changes. The authors' study highlights a positive connection between the economic growth and the level of the expenses with the education of the students between the ages of 18 and 26 years and the expenses with the research and development and the degree of employment of the fresh graduates. The authors also concluded the indicator regarding the perception of corruption is negatively associated with economic development.

Mdanat et al. (2018) analyzes the structure of taxes and their implications in respect with the economic growth in Jordan for a period between 1980 and 2015 by using error correction techniques. The authors' study provides empirical evidence which entails that direct and indirect tax structure is an insufficient indicator in highlighting the policy makers because Jordan faces poor fiscal performance and has an inefficient fiscal structure that should determine politicians that within their politics to focus more on increasing the GDP per capita by addressing the importance of consumption taxes and customs duties. Furthermore, the authors believe a sustainable economic growth could only be achieved if poverty and inequalities are to be reduced and living conditions to be improved. The research studies performed by Arnold (2008), Arnold et al. (2011) have significantly influenced the political debates at the level of OECD countries and European Commission which recommends the orientation towards a fiscal structure that encourages economic growth. Many of the studies on the same topic undertaken by Jones et al. (1993), Barro (1990) include models of endogenous growth in order to analyze the economic effects of the fiscal structure and policy measures, which are the most significant endogenous variables that help quantify the impact that fiscal policy has on the long-term economic growth. Barro (1990) also incorporated in its models as main endogenous variable the fiscal policy and emphasized that public expenditure has positive impact and stimulates the longterm growth.

Additionally, Capolupo (2000) studies the long-term effects of the governmental expenditure and taxation by applying an endogenous growth model similar to the model projected by Barro (1990), but slightly modified by means that Capolupo (2000) correlated the human capital growth rate with the governmental expenditure in public education. The results of his research are compliant with other similar studies that analyze the manner in which the public expenses are used for productive purposes and have positive impact upon the economic growth. Lucas (1988) states that the distortions resulting from fiscal policy have negative

DOI: 10.24818/18423264/55.2.21.14 
effects on economic growth, but his results are not significant when additional variables are introduced in the model in order to counteract such negative effects of the fiscal policy factors. Other researchers such as Sturm et al. (1998) tested and investigated the model of endogenous growth proposed by Barro (1990), but did not find clear empirical evidence to support that governmental expenditure considered as economic control variable affects the possibilities of production and growth. Rao (2010) shows that many of the empirical studies based on previous endogenous growth models are disconcerting, some of which are even exogenous growth models. Thus, Rao (2010) determines that the basic equation used in the proposed model of long-term economic growth is basically a production function.

Recent studies regarding the impact of taxation on economic growth: Arnold et al. (2011), Gemmell et al. (2011) offer much more specific solutions, which include how changes in the structure of taxes and duties affect long-term economic growth. On the other hand, researchers like Aliani et al. (2017) conclude that there are other factors such as the personality and self-confidence of CEOs of companies, which influence fiscal policies and have negative effects on the taxes applied to companies. Although over time endogenous growth models have been applied to quantify the relationship between fiscal policy and economic growth, economists are aware that these empirical results are inconsistent and inconclusive, so applying an endogenous growth model in a country reveals the presence of weaknesses and non-robust results. Reed (2008) justifies by means of his estimation techniques that the fiscal burden has negative effects on economic growth and Arin and Koray (2006) use a VAR model to examine the impact of various fiscal policies that encourage economic growth in Canada. Munir and Sultan (2018) analyze the short- and long-term relationship between direct and indirect taxes and economic growth in Pakistan by estimating time series between 1976 and 2014 and by using the distributive lag model. The authors conclude that there is a long-term link between taxes and the real growth of gross domestic product. Furthermore, Fetai et al. (2017) study the main factors that influence the economic growth in the Eastern Balkan countries for a period of time between 1994 and 2015 by using the following techniques: OLS method with robust errors, fixed and random effects and the Hausman-Taylor model with instrumental variables. The results highlighted that foreign direct investments, savings and loans contracted by the private sector have positive effects on economic growth per capita. On the other hand, corruption, unemployment and government spending have negative impact on the economic growth per capita. Moreover, the researchers draw attention to the fact that it is relevant to attract a large volume of foreign direct investment in order to reduce the level of corruption. Bayar and Aytemiz (2019) study the causality between the indicators of misery and corruption on income inequality in Latin American countries, considering the process of globalization as their main influence factor. The authors argue that a considerable global growth in trade in goods, services and financial assets has been noticeable in the last 40 years, but Latin America is still a region in which poverty and income

DOI: $10.24818 / 18423264 / 55.2 .21 .14$ 
Does Fiscal Policy Influence the Economic Growth? - Evidence from OECD Countries

inequalities are present. The time period analyzed in the study is represented by the years 2002-2014 and the estimation methodology includes the LM bootstrap cointegration test and the causal test of the Granger panel data. The results showed that an increase in the indicators of misery and corruption plays an important role in increasing the income inequality. Moreover, researchers emphasize that it is relevant for an economy to attract a large volume of foreign direct investment in order to reduce the level of corruption.

\section{Research Methodology}

\subsection{Database and Variables Used in the Empirical Analysis}

The analysis of the social and economic impact that taxation exerts upon the economic growth rate and the final consumer, is based on an econometrical estimation which aims to quantify the influence of the decisive factors represented by the fiscal variables, the public governance indicators and economic control variables. The econometrical estimation of the consumption taxes and other fiscal variables in the OEDC member countries is performed by taking in consideration eight regression equations for a period of time between $2002-2017$ with a Panel data consolidated with information published on websites such as Eurostat, MyHeritage, WorldBank and OECD. The dependent variable used in the econometrical analysis is represented by the economic growth rate and the following are the independent variables: taxes levied on goods and services, taxes on personal income, taxes on corporate profits, social security contributions, taxes on payroll, taxes on property, imports, gross fixed capital formation, public expenditure, household consumption, tax wedge, fiscal freedom index and the world governance indicators. Table 1 shows the variables of the studies together with their descriptions, sources and the model in which they are used.

Table 1. The variables used in the econometric models - period 2002 - 2017

\begin{tabular}{|c|c|c|}
\hline Variable & Description & Source \\
\hline \multicolumn{3}{|c|}{ Dependent Variable } \\
\hline $\begin{array}{l}\text { Economic Growth Rate } \\
\text { (GDP GRATE) }\end{array}$ & Annual real growth rate of Gross Domestic Product (GDP) & Eurostat \\
\hline \multicolumn{3}{|c|}{ Independent Variables } \\
\hline \multicolumn{3}{|c|}{ Fiscal Variables } \\
\hline $\begin{array}{l}\text { Taxes on goods and services(GS_TAX) } \\
\text { Model } 1,8\end{array}$ & $\begin{array}{l}\text { Includes all taxes applied to the production processes, extraction, sales, transfer of } \\
\text { ownership of goods or to goods in leasing. It also includes the taxes applied to the } \\
\text { provision of services. These consist mainly of VAT and other consumption taxes (excise } \\
\text { duties, GST), customs duties, taxes applied to the extraction and processing of mining and } \\
\text { petroleum products. Variable expressed as percentage of the total tax revenue in a year. }\end{array}$ & \multirow{7}{*}{$\begin{array}{l}\text { The online } \\
\text { OECD } \\
\text { database }\end{array}$} \\
\hline $\begin{array}{l}\text { Total tax revenues(TOT_TAX) } \\
\text { Model } 2\end{array}$ & $\begin{array}{l}\text { Total tax revenues collected from income taxes, taxes on corporate profits, social security } \\
\text { contributions, taxes applied to goods and services, property taxes, taxes applied to the } \\
\text { transfer of property and other taxes. The values of the variable are measured as GDP } \\
\text { percentage and indicate the volume of taxes and duties collected by the government. }\end{array}$ & \\
\hline $\begin{array}{l}\text { Taxes on personal income(INC_TAX) } \\
\text { Model } 3,8\end{array}$ & $\begin{array}{l}\text { Includes taxes on personal income and capital gains of individuals. This indicator is } \\
\text { measured as GDP percentage. }\end{array}$ & \\
\hline $\begin{array}{l}\text { Taxes on corporate profits(PROF_TAX) } \\
\text { Model } 4,8\end{array}$ & $\begin{array}{l}\text { This variable includes the taxes applied to corporate profits and other capital gains. This } \\
\text { indicator is measured as GDP percentage. }\end{array}$ & \\
\hline $\begin{array}{l}\text { Social security } \\
\text { contributions(SOC_TAX) } \\
\text { Model } 5,8\end{array}$ & $\begin{array}{l}\text { Social security contributions paid by taxpayers that include unemployment allowances, } \\
\text { contributions to pensions and health funds. The indicator is measured as GDP percentage. }\end{array}$ & \\
\hline $\begin{array}{l}\text { Taxes on payroll(SAL_TAX) } \\
\text { Model } 6,8\end{array}$ & $\begin{array}{l}\text { Taxes on payroll are paid by the employees, employers or freelancers, either as percentage } \\
\text { of the salary or as a fixed amount per person. This indicator does not confer a social benefit } \\
\text { and is measured as GDP percentage. }\end{array}$ & \\
\hline Taxes on property(OWN_TAX) & Recurring and non-recurring taxes applied on the use, possession or transfer of property. & \\
\hline
\end{tabular}

DOI: 10.24818/18423264/55.2.21.14 
GeorgetaVintilă, Ștefan Cristian Gherghina, Ștefania Cosmina Chiricu

\begin{tabular}{|c|c|c|}
\hline Model 7,8 & $\begin{array}{l}\text { These include taxes applied to immovable property, taxes applied to the exchange of } \\
\text { property by inheritance or donation, as well as taxes applied on financial and capital } \\
\text { transactions. The variable is measured as GDP percentage. }\end{array}$ & \\
\hline $\begin{array}{c}\text { Tax wedge(TAX_WEDGE) } \\
\text { All models }\end{array}$ & $\begin{array}{l}\text { The ratio between the total cost corresponding to the work for an employer and the amount } \\
\text { of taxes and fees paid by an average-wage employee with no children. The average tax } \\
\text { burden measures the level to which taxes on wages discourage employment. This indicator } \\
\text { is measured as a percentage of the cost of the work performed. }\end{array}$ & \\
\hline & Public Governance Indicators & \\
\hline $\begin{array}{l}\text { Tax Freedom Index(TAX_FREE) } \\
\text { All models }\end{array}$ & $\begin{array}{l}\text { It measures the tax burden imposed by governments through fiscal policies and consists of } \\
\text { three quantitative factors:marginal share of personal income tax, marginal share of } \\
\text { corporate income tax and the total tax burden measured as percentage of GDP. }\end{array}$ & $\begin{array}{l}\text { The Heritage } \\
\text { Foundation } \\
\text { online } \\
\text { database }\end{array}$ \\
\hline $\begin{array}{l}\text { Voice Accountability(VOICE_ACC) } \\
\text { All models }\end{array}$ & $\begin{array}{l}\text { Voice and accountability is one of the six indicators of public governance that measures } \\
\text { citizens' perception of the degree at which they have the opportunity to participate in the } \\
\text { choice of their own government, as well as freedom of expression, association and freedom } \\
\text { for the media. }\end{array}$ & \multirow{6}{*}{$\begin{array}{l}\text { Worldwide } \\
\text { Governance } \\
\text { Indicators }\end{array}$} \\
\hline $\begin{array}{l}\text { Political Stability and Absence of } \\
\text { Violence/Terrorism (POL_STAB) } \\
\text { All models }\end{array}$ & $\begin{array}{l}\text { Measures the perception of citizens about the possibility of a government destabilization } \\
\text { due to unconstitutional practices motivated by acts of violence or terrorism. It is a } \\
\text { composite index, computed as the average of other indices from multiple sources }\end{array}$ & \\
\hline $\begin{array}{l}\text { Government effectiveness (GOV_EFF) } \\
\text { All models }\end{array}$ & $\begin{array}{l}\text { Measures the perception of the quality of public services as well as the citizens' degree of } \\
\text { independence from political pressures, the quality of public policies and the government } \\
\text { involvement in their implementation. }\end{array}$ & \\
\hline $\begin{array}{l}\text { Regulatory quality(REG_QLTY) } \\
\text { All models }\end{array}$ & $\begin{array}{l}\text { Measures the government's ability to formulate and implement stable policies and } \\
\text { regulations that allow the development of the private sector. }\end{array}$ & \\
\hline $\begin{array}{l}\text { Rule of law(RULE_LAW) } \\
\text { All models }\end{array}$ & $\begin{array}{l}\text { Quantifies the perception of the degree to which state agents trust and obey the rules of } \\
\text { society as well as in the performance of contracts, property rights, police and courts and } \\
\text { also of the probability of acts of violence and crime to be triggered. }\end{array}$ & \\
\hline $\begin{array}{l}\text { Control of corruption (CORR_CTRL) } \\
\text { All models }\end{array}$ & $\begin{array}{l}\text { Control of Corruption is an indicator that measures the perception of the degree to which } \\
\text { public authority is exerted for the purpose of personal gain, including large and small type } \\
\text { of corruption as well as the securement of states by private and elite interests. }\end{array}$ & \\
\hline \multicolumn{3}{|c|}{ Economic Control Variables } \\
\hline $\begin{array}{l}\text { Gross fixed capital } \\
\text { formation(CAPITAL) } \\
\text { All models }\end{array}$ & $\begin{array}{l}\text { Gross fixed capital formation is measured as GDP percentage and is defined as the net } \\
\text { procurement of the resident units of goods and services which were produced during the } \\
\text { period considered, but not consumed. It includes gross fixed capital formation and cost } \\
\text { variations. }\end{array}$ & \multirow{3}{*}{ Eurostat } \\
\hline $\begin{array}{l}\text { Imports(IMPORTS) } \\
\text { All models }\end{array}$ & The amount of imports performed by a country, measured as GDP percentage. & \\
\hline $\begin{array}{l}\text { Government expenditure(GOV_EXP) } \\
\text { All models }\end{array}$ & Public government expenditure, measured as GDP percentage. & \\
\hline $\begin{array}{l}\text { Household final consumption } \\
\text { expenditure(SPEND) } \\
\text { All models }\end{array}$ & $\begin{array}{l}\text { This variable is defined as the amount of final consumption expenditures made by resident } \\
\text { households in order to meet daily needs such as food, clothing, rent, energy, transportation, } \\
\text { and other expenses. The variable is measured as GDP percentage. }\end{array}$ & $\begin{array}{l}\text { The online } \\
\text { OECD } \\
\text { database }\end{array}$ \\
\hline
\end{tabular}

\subsection{Description of the Empirical Methods}

The empirical approach of the research is performed by estimating eight multiple regression equations. The data is arranged in Panel type models with cross sections and the analyzed time period is between $2002-2017$ for the 36 OECD member countries.

The basic regression equation is the following:

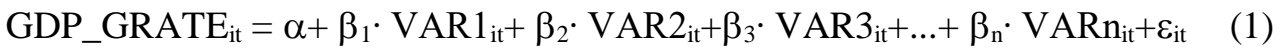

Where $\mathrm{i}$ corresponds to the analyzed country (OECD-36), VAR represents the independent variable and $t$ corresponds to the year $(2002-2017)$. The parameters of the econometric testing hypothesis are

$\mathrm{H}_{0}: \beta_{1}=\beta_{2}=\beta_{3}=\beta_{4}=\ldots=\beta_{\mathrm{n}}$

$\mathrm{H}_{1}$ : there is at least one $\beta_{1} \neq 0$

Starting from the basic regression equation, we estimated the proposed models by gradually including each fiscal variable as independent factor. The regression equations are estimated by applying the least squares method and the generalized method of moments - GMM (Armeanu et al., 2018, Gherghina et al., 2018). The use of GMM method is considered to improve the efficiency of the

DOI: $10.24818 / 18423264 / 55.2 .21 .14$ 
Does Fiscal Policy Influence the Economic Growth? - Evidence from OECD Countries

variables and to eliminate the discrepancies caused by the variables that have weak influence on the economic growth rate. Moreover, the GMM method minimizes data loss and the differences caused by the panel structured data. The instrumental variables in the GMM estimates are: Political stability and the absence of terrorism or violence; Voice and accountability; Government effectiveness; Regulatory quality; Rule of the law and the Control of corruption. Moreover, depending on the results of the Hausman tests, the estimation with the least squares method (OLS) was performed both without effects and with fixed or random effects.

\section{Results of the Quantitative Research}

\subsection{Results of the Estimation of the Econometric Models}

The descriptive statistics of the variables are presented in Table 2 and include the average, maximum and minimum value and standard deviation, together with the number of observations.

Table 2. Descriptive statistics of the variables

\begin{tabular}{|c|c|c|c|c|c|}
\hline & Mean & Maximum & Minimum & Std. Dev. & Observations \\
\hline GDP_GRATE & 2.3605 & 25.1172 & -14.8141 & 3.3114 & 494 \\
\hline$G \bar{S} \_T A X$ & 31.6373 & 49.4300 & 15.8500 & 7.0520 & 494 \\
\hline$T O \bar{T}_{-} T A X$ & 34.0563 & 51.5950 & 11.3620 & 7.4879 & 494 \\
\hline$I N C_{-} T A X$ & 8.7573 & 26.3490 & 2.6480 & 4.1794 & 494 \\
\hline PROF_TAX & 2.9840 & 12.5940 & 0.58600 & 1.5644 & 494 \\
\hline SOC_TAX & 9.1171 & 16.9120 & 0 & 4.4957 & 494 \\
\hline$S A L_{-} T A X$ & 0.3930 & 5.0570 & 0 & 0.8525 & 494 \\
\hline$O W N_{-} T A X$ & 1.8723 & 17.6340 & 0.2170 & 1.2950 & 494 \\
\hline$T A X_{-} \overline{W E D G E}$ & 38.0961 & 56.3312 & 15.8690 & 8.8088 & 494 \\
\hline$T A \bar{X}_{-} F R E E$ & 62.3664 & 90 & 30 & 13.0647 & 494 \\
\hline$V O I C E_{-} A C C$ & 1.2123 & 1.8000 & -0.7100 & 0.3816 & 494 \\
\hline POL_STAB & 0.7849 & 1.7600 & -2.0100 & 0.6346 & 494 \\
\hline$G O V_{-} E F F$ & 1.3909 & 2.3500 & 0.0100 & 0.5285 & 494 \\
\hline$R E G_{-} Q L T Y$ & 1.3570 & 2.0900 & 0.0400 & 0.3947 & 494 \\
\hline$R U L E_{-} L A W$ & 1.3689 & 2.1000 & -0.2500 & 0.5491 & 494 \\
\hline CORR_CTRL & 1.3724 & 2.4700 & -0.5200 & 0.7525 & 494 \\
\hline CAPITAL & 23.0385 & 41.5384 & 12.3711 & 4.1327 & 494 \\
\hline IMPORTS & 47.7777 & 191.5485 & 9.6673 & 27.8370 & 494 \\
\hline GOV_EXP & 19.7552 & 27.9350 & 10.9092 & 3.3612 & 494 \\
\hline$S P E N D$ & 12.2467 & 16.3741 & 8.4971 & 1.6354 & 494 \\
\hline
\end{tabular}

Out of the tested variables the maximum value recorded is of $191.54 \%$ and represents the share of imports in GDP registered by Luxembourg, year 2015. However, the minimum value recorded was of $-14.81 \%$ economic growth registered by Lithuania in 2009. On the other hand, the average values of the global governance indicators are positive, with values ranging from -2.5 (weak) to 2.5 (strong) as related to the measurement as standard distribution of these indicators. Each of the models are based on the variables presented in Table 1 of the research methodology and the estimation methods are the least squares method - OLS and the generalized method of moments - GMM. Moreover, we also estimated a main fiscal variable for each econometric model in order to determine precise results and to remove the negative effects caused by the lack of data for which we have adjusted the analyzed period. Table 3 and Table 4 summarize the results of the estimated coefficients of each explanatory variable, respectively by applying the least squares method without effects (Table 3) and with fixed or random effects

DOI: 10.24818/18423264/55.2.21.14 
(Table 4). The fiscal variable related to the first model is represented by taxes on goods and services, therefore the results of our study affirm that taxes on goods and services support economic growth. Also, imports (significant - without effects: model 1, 5, 8; with effects: model 1, 3, 4, 5, 7, 8) and gross fixed capital formation (without effects / with effects: all models) have positive impact on the economic growth rate because imports lead to economic growth as long as the goods imported are used in association with or to replace certain products and materials needed within an economic environment and also for economic agents to continue their activities. Much more, a large volume of imports implies a similar large volume of customs duties collection. The rationale for estimating the imports as variable reveals, as indicated by Kim et al. (2007), that the effects of imports on economic growth and productivity are explained by the competitive pressures generated by good imports and technology transfers of capital in developed countries.On the other hand, government expenditure has negative effects on the dependent variable, both in the estimation without effects and with effects for all the models, fact that highlights an unproductive management of them. Considering the public governance indicators, the results determined that the Rule of law indicator is significant in the no-effect estimation for models $3,4,7,8$ and in the effect estimation for models 1, 3, 4, 5, 7 and 8, thus highlighting an economic drop, which can, according to Haggard and Tiede (2011) be explained by the subjective nature of the indicator and by the correlations between the institutions that this indicator captures. Moreover, the negative effects are proved because of the different legislative systems in the countries analyzed, the risks of expropriations and by the level of violence and terrorism. Haggard and Tiede (2011) also suggest the implementation of a program based on the research of the size of the rule of law and its impact on economic growth.

The second model of the empirical analysis includes as fiscal independent variable the Total tax revenues (TOT_TAX) measured as GDP percentage with positive effects on economic growth. In the no-effect estimation, the TOT_TAX variable is not significant, however in the fixed-effect estimation total tax revenues are significant, thus a one-unit increase in tax revenues will increase the economic growth rate by 0.11 percent.

Furthermore, the following independent variables are significant and have positive impact on the economic growth: the degree of Control corruption (significance - without effects: models 2, 3, 4, 7; with effects: model 3), the Regulatory quality and Governanment effectiveness (significance - without effects: models 2, 3, 4, 7, with effects: model 3). 
Does Fiscal Policy Influence the Economic Growth? - Evidence from OECD Countries

\begin{tabular}{|c|c|c|c|c|c|c|c|c|}
\hline \multicolumn{9}{|c|}{ Table 3. Least Squares Method (OLS) estimation results - No effects } \\
\hline & \multicolumn{8}{|c|}{ OLS - NOEFECTS } \\
\hline $\begin{array}{c}\text { Dependent Variable: } \\
\text { GDP_GRATE }\end{array}$ & Model I & Model 2 & Model 3 & Model 4 & Model 5 & Model 6 & Model 7 & Model 8 \\
\hline \multicolumn{9}{|l|}{ Fiscal Variables: } \\
\hline$G S \_T A X$ & $\begin{array}{c}0.1013 * * \\
(0.0013)\end{array}$ & & & & & & & $\begin{array}{l}0.1494 * \\
(0.0002)\end{array}$ \\
\hline$T O T \_T A X$ & & $\begin{array}{c}0.0221 \\
(0.5856)\end{array}$ & & & & & & \\
\hline$I N C \_T A X$ & & & $\begin{array}{c}0.0158 \\
(0.7385)\end{array}$ & & & & & $\begin{array}{r}-0.0669 \\
(0.3912)\end{array}$ \\
\hline PROF_TAX & & & & $\begin{array}{l}-0.0517 \\
(0.5899)\end{array}$ & & & & $\begin{array}{r}-0.0473 \\
(0.6397)\end{array}$ \\
\hline$S O C \_T A X$ & & & & & $\begin{array}{l}-0.1688 * \\
(0.0012)\end{array}$ & & & $\begin{array}{l}-0.1182 \\
(0.1538)\end{array}$ \\
\hline$S A L \_T A X$ & & & & & & $\begin{array}{c}0.0349 \\
(0.8938)\end{array}$ & & $\begin{array}{c}0.2976 \\
(0.1003)\end{array}$ \\
\hline$O W N_{-} T A X$ & & & & & & & $\begin{array}{l}0.3315^{*} \\
(0.0058)\end{array}$ & $\begin{array}{l}0.5463^{*} \\
(0.0001)\end{array}$ \\
\hline$T A X_{-} W E D G E$ & $\begin{array}{r}0.0107 \\
(0.5673)\end{array}$ & $\begin{array}{c}0.0022 \\
(0.9171)\end{array}$ & $\begin{array}{r}-0.0049 \\
(0.8003) \\
\end{array}$ & $\begin{array}{r}-0.0079 \\
(0.6981) \\
\end{array}$ & $\begin{array}{c}0.0476 * * * \\
(0.0766) \\
\end{array}$ & $\begin{array}{r}0.0335 \\
(0.4389) \\
\end{array}$ & $\begin{array}{c}0.0106 \\
(0.5965) \\
\end{array}$ & $\begin{array}{c}0.0185 \\
(0.5920) \\
\end{array}$ \\
\hline \multicolumn{9}{|c|}{ Public Governance Indicators: } \\
\hline \multirow[t]{2}{*}{ TAX_FREE } & $\stackrel{-}{0.0243 * * *}$ & $\stackrel{-}{-} 0.0240 * * *$ & $\begin{array}{c}- \\
0.0264 * * *\end{array}$ & $\stackrel{-}{0.0253^{* * * *}}$ & -0.0234 & 0.0142 & $\overline{-}^{-} .0319^{* * *}$ & $0.0335^{* *}$ \\
\hline & $(0.0796)$ & $(0.0980)$ & $(0.0738)$ & $(0.0782)$ & $(0.1171)$ & $(0.5577)$ & $(0.0236)$ & $(0.0413)$ \\
\hline \multirow[t]{2}{*}{$R U L E \_L A W$} & -1.3210 & -1.2447 & $-3.2774 *$ & $-2.8890^{*}$ & -0.7989 & -1.7958 & $-3.2615^{*}$ & $2.3510^{* *}$ \\
\hline & $(0.1184)$ & $(0.1122)$ & $(0.0013)$ & $(0.0049)$ & $(0.3947)$ & $(0.3673)$ & $(0.0011)$ & $(0.0334)$ \\
\hline$R E G_{-} Q L T Y$ & $\begin{array}{c}0.8286 \\
(0.2778)\end{array}$ & $\begin{array}{c}1.6884 * * \\
(0.0255)\end{array}$ & $\begin{array}{c}1.4197 * * * \\
(0.0741)\end{array}$ & $\begin{array}{c}1.4479^{* * * *} \\
(0.0588)\end{array}$ & $\begin{array}{c}0.6967 \\
(0.4059)\end{array}$ & $\begin{array}{c}1.5198 \\
(0.2427)\end{array}$ & $\begin{array}{l}1.9757^{*} \\
(0.0091)\end{array}$ & $\begin{array}{c}-0.0592 \\
(0.9459)\end{array}$ \\
\hline$P O L \_S T A B$ & $\begin{array}{l}-0.2345 \\
(0.5202)\end{array}$ & $\begin{array}{l}-0.2810 \\
(0.4467)\end{array}$ & $\begin{array}{l}-0.0588 \\
(0.8742)\end{array}$ & -0.2232 & $\begin{array}{r}-0.1450 \\
-(07083)\end{array}$ & $-1.8983^{*}$ & 0.1897 & $\begin{array}{l}0.4311 \\
0.2674)\end{array}$ \\
\hline$G O V \_E F F$ & $\begin{array}{c}(0.5202) \\
0.8300\end{array}$ & $\begin{array}{c}(0.4467) \\
0.3507\end{array}$ & $\begin{array}{c}(0.8742) \\
0.6604\end{array}$ & $\begin{array}{c}(0.5507) \\
0.6868\end{array}$ & $\begin{array}{c}(0.7083) \\
0.5664\end{array}$ & $\begin{array}{c}(0.0056) \\
1.8356\end{array}$ & $\begin{array}{c}(0.6177) \\
0.5860\end{array}$ & $\begin{array}{l}(0.2674) \\
2.1589^{*}\end{array}$ \\
\hline \multirow[t]{2}{*}{$V O I C E \_A C C$} & $\begin{array}{c}(0.2991) \\
-0.4058\end{array}$ & $\begin{array}{l}(0.6289) \\
-1.3505\end{array}$ & $\begin{array}{c}(0.4085) \\
-1.3910\end{array}$ & $\begin{array}{c}(0.3902) \\
-1.0981\end{array}$ & $\begin{array}{c}(0.5001) \\
-0.9277\end{array}$ & $\begin{array}{c}(0.2766) \\
2.1829\end{array}$ & $\begin{array}{c}(0.4564) \\
-1.9170 * *\end{array}$ & $\begin{array}{c}(0.0094) \\
0.1567\end{array}$ \\
\hline & $(0.6866)$ & $(0.1664)$ & $(0.1479)$ & $(0.2671)$ & $(0.3651)$ & $(0.3234)$ & $(0.0487)$ & $(0.8825)$ \\
\hline CORR_CTRL & $\begin{array}{c}0.7372 \\
(0.2180)\end{array}$ & $\begin{array}{c}0.5152^{* * * *} \\
(0.0566)\end{array}$ & $\begin{array}{c}1.5472 * * \\
(0.0190)\end{array}$ & $\begin{array}{c}1.2061^{* * * *} \\
(0.0599)\end{array}$ & $\begin{array}{c}0.1333 \\
(0.8460)\end{array}$ & $\begin{array}{r}-0.0047 \\
(0.9975)\end{array}$ & $\begin{array}{l}1.3854^{* *} \\
(0.0257)\end{array}$ & $\begin{array}{c}0.0997 \\
(0.8891)\end{array}$ \\
\hline \multicolumn{9}{|l|}{ Economic Control Variables: } \\
\hline CAPITAL & $\begin{array}{l}0.3029^{*} \\
(0.0000)\end{array}$ & $\begin{array}{l}0.2897^{*} \\
(0.0000)\end{array}$ & $\begin{array}{l}0.2832^{*} \\
(0.0000)\end{array}$ & $\begin{array}{l}0.2654^{*} \\
(0.0000)\end{array}$ & $\begin{array}{l}0.3231^{*} \\
(0.0000)\end{array}$ & $\begin{array}{l}0.2244 * \\
(0.0013)\end{array}$ & $\begin{array}{l}0.2844 * \\
(0.0000)\end{array}$ & $\begin{array}{l}0.3328 * \\
(0.0000)\end{array}$ \\
\hline IMPORTS & $\begin{array}{c}0.0151^{* *} \\
(0.0292)\end{array}$ & $\begin{array}{c}0.0083 \\
(0.2126)\end{array}$ & $\begin{array}{c}0.0104 \\
(0.1289)\end{array}$ & $\begin{array}{c}0.0095 \\
(0.1624)\end{array}$ & $\begin{array}{c}0.0185^{* *} \\
(0.0149)\end{array}$ & $\begin{array}{c}0.0086 \\
(0.6533)\end{array}$ & $\begin{array}{c}0.0065 \\
(0.3372)\end{array}$ & $\begin{array}{l}0.0224 * \\
(0.0030)\end{array}$ \\
\hline \multirow[t]{2}{*}{ GOV_EXP } & $-0.2056^{*}$ & $-0.2180 *$ & $-0.2177^{*}$ & $-0.2080 *$ & $-0.1725 *$ & $-0.3326^{*}$ & $-0.2382^{*}$ & $-0.2134 *$ \\
\hline & $(0.0001)$ & $(0.0003)$ & $(0.0001)$ & $(0.0001)$ & $(0.0020)$ & $(0.0042)$ & $(0.0000)$ & $(0.0003)$ \\
\hline \multirow[t]{2}{*}{ SPEND } & 0.0396 & $-0.2857 * *$ & $-0.2510^{* * *}$ & $-0.2585 * *$ & -0.0863 & $-0.7191 *$ & $-0.3476^{*}$ & 0.2054 \\
\hline & $(0.7940)$ & $(0.0129)$ & $(0.0331)$ & $(0.0257)$ & $(0.5055)$ & $(0.0020)$ & $(0.0041)$ & $(0.2053)$ \\
\hline $\begin{array}{c}\text { Observations } \\
\text { Obsuod }\end{array}$ & $\begin{array}{c}560 \\
0.2592\end{array}$ & 560 & 528 & 528 & 514 & 192 & 546 & 496 \\
\hline Aajustea K-Squarea & 0.2592 & 0.2490 & 0.2665 & 0.2401 & 0.2588 & 0.2000 & 0.2736 & 0.2940 \\
\hline$F$-statistic & 16.04641 & 15.23523 & 15.70634 & 13.81293 & 14.78181 & 4.826849 & 16.79446 & 12.45253 \\
\hline $\operatorname{Prob}(F$-statistic) & 0.000000 & 0.000000 & 0.000000 & 0.000000 & 0.000000 & 0.000000 & 0.000000 & 0.000000 \\
\hline
\end{tabular}

Source: Authors' own processing; * Level of significance 1\%; ** Level of significance 5\%; *** Level of significance $10 \%$; The brackets enclose the statistical probabilities of the estimated coefficients.

Other independent variables with negative impact are Fiscal freedom (without effects: models 1, 2, 3, 4, 7, 8; with effects: models 2 and 3) and Private consumption of households (without effects: models 2, 3, 4, 6, 7, with effects: models: 2 and 3). Therefore, the increase by one unit of Private consumption of households negatively impacts the economic growth because the goods and services demanded and consumed daily do not provide a fair level of profitability for the economic operators and producers who will be determined to cope with the market changes in order to make new investments and create new jobs.

DOI: 10.24818/18423264/55.2.21.14 
GeorgetaVintilă, Ștefan Cristian Gherghina, Ștefania Cosmina Chiricu

Table 4. Least Squares Method (OLS) estimation results - With effects

\begin{tabular}{|c|c|c|c|c|c|c|c|c|}
\hline \multirow[b]{2}{*}{$\begin{array}{r}\text { Dependent Variable: } \\
\text { GDP_GRATE }\end{array}$} & \multicolumn{8}{|c|}{ OLS - FIXED/RANDOM EFFECTS } \\
\hline & $\begin{array}{l}\text { Model 1 } \\
\text { Fixed } \\
\text { effects }\end{array}$ & $\begin{array}{l}\text { Model } 2 \\
\text { Fixed } \\
\text { effects }\end{array}$ & $\begin{array}{l}\text { Model } 3 \\
\text { Random } \\
\text { effects }\end{array}$ & $\begin{array}{l}\text { Model } 4 \\
\text { Fixed } \\
\text { effects }\end{array}$ & $\begin{array}{l}\text { Model } 5 \\
\text { Fixed } \\
\text { effects }\end{array}$ & $\begin{array}{l}\text { Model 6 } \\
\text { Fixed } \\
\text { effects }\end{array}$ & $\begin{array}{l}\text { Model } 7 \\
\text { Fixed } \\
\text { effects }\end{array}$ & $\begin{array}{l}\text { Model } 8 \\
\text { Fixed } \\
\text { effects }\end{array}$ \\
\hline \multicolumn{9}{|l|}{ Fiscal Variables: } \\
\hline$G S \_T A X$ & $\begin{array}{l}0.1948 * * \\
(0.0048)\end{array}$ & & & & & & & $\begin{array}{l}(0.0111) \\
-0.1264\end{array}$ \\
\hline$T O T \_T A X$ & & $\begin{array}{c}0.1123 * * * \\
(0.0521)\end{array}$ & & & & & & \\
\hline$I N C_{-} T A X$ & & & $\begin{array}{l}-0.0055 \\
(0.8945)\end{array}$ & & & & & $\begin{array}{c}0.0249 \\
(0.9049)\end{array}$ \\
\hline PROF_TAX & & & & $\begin{array}{l}-0.2797 \\
(0.1389)\end{array}$ & & & & $\begin{array}{l}-0.0220 \\
(0.9176)\end{array}$ \\
\hline SOC_TAX & & & & & $\begin{array}{c}-0.3457 * * * \\
(0.0689)\end{array}$ & & & $\begin{array}{c}- \\
0.3379^{* * *} \\
(0.0965)\end{array}$ \\
\hline$S A L \_T A X$ & & & & & & $\begin{array}{c}0.6269 \\
(0.2444)\end{array}$ & & $\begin{array}{l}-0.1264 \\
(0.8450)\end{array}$ \\
\hline$O W N \_T A X$ & & & & & & & $\begin{array}{c}0.2801 * * * \\
(0.0886)\end{array}$ & $\begin{array}{l}0.4348 * * \\
(0.0124)\end{array}$ \\
\hline$T A X \_W E D G E$ & $\begin{array}{l}0.3029 * \\
(0.0005)\end{array}$ & $\begin{array}{c}0.0192 \\
(0.6520)\end{array}$ & $\begin{array}{l}-0.0207 \\
(0.2295)\end{array}$ & $\begin{array}{l}0.2292^{*} \\
(0.0062)\end{array}$ & $\begin{array}{l}0.2264 * \\
(0.0094)\end{array}$ & $\begin{array}{l}0.1237 \\
(0.2957) \\
\end{array}$ & $\begin{array}{c}0.1749 * * \\
(0.0340) \\
\end{array}$ & $\begin{array}{l}0.3543^{*} \\
(0.0012) \\
\end{array}$ \\
\hline \multicolumn{9}{|l|}{$\begin{array}{r}\text { Public Governance } \\
\text { Indicators: }\end{array}$} \\
\hline TAX_FREE & $\begin{array}{l}-0.0253 \\
(0.4432)\end{array}$ & $\begin{array}{c}-0.0559^{* * *} \\
(0.0210)\end{array}$ & $\begin{array}{c}-0.0221 * * * \\
(0.0967)\end{array}$ & $\begin{array}{c}-0.0142 \\
(0.6819)\end{array}$ & $\begin{array}{r}-0.0306 \\
(0.3793)\end{array}$ & $\begin{array}{l}-0.1063 \\
(0.1362)\end{array}$ & $\begin{array}{r}-0.0240 \\
(0.4797)\end{array}$ & $\begin{array}{l}-0.0061 \\
(0.8634)\end{array}$ \\
\hline$R U L E \_L A W$ & $\begin{array}{c}-3.3947 * * \\
(0.0158)\end{array}$ & -1.4265 & $\begin{array}{c}-2.3047 * * \\
(0.0135)\end{array}$ & $\begin{array}{c}-2.6775 * * * \\
(0.0795)\end{array}$ & $\begin{array}{c}-3.6343 * * \\
(0.0158)\end{array}$ & $\begin{array}{l}4.1758 \\
(0.1180)\end{array}$ & $\begin{array}{c}-3.1468^{* * *} \\
(0.0314)\end{array}$ & $\begin{array}{l}-3.1572 * * \\
(0.0447)\end{array}$ \\
\hline$R E G_{-} Q L T Y$ & $\begin{array}{c}1.4103 \\
(0.2069)\end{array}$ & $\begin{array}{c}0.1000 \\
(0.9220)\end{array}$ & $\begin{array}{l}1.4599 * * \\
(0.0366)\end{array}$ & $\begin{array}{c}1.3436 \\
(0.2552)\end{array}$ & $\begin{array}{c}1.0181 \\
(0.4170)\end{array}$ & $\begin{array}{c}0.1787 \\
(0.9314)\end{array}$ & $\begin{array}{c}1.1487 \\
(0.3240)\end{array}$ & $\begin{array}{c}1.1513 \\
(0.3508)\end{array}$ \\
\hline POL_STAB & $\begin{array}{c}0.8310 \\
(0.2021)\end{array}$ & $\begin{array}{l}-0.4020 \\
(0.4814)\end{array}$ & $\begin{array}{c}0.1827 \\
(0.5818)\end{array}$ & $\begin{array}{c}0.7477 \\
(0.2731)\end{array}$ & $\begin{array}{c}0.8935 \\
(0.1974)\end{array}$ & $\begin{array}{c}0.8656 \\
(0.5037)\end{array}$ & $\begin{array}{c}1.0827 \\
(0.1019)\end{array}$ & $\begin{array}{c}0.3557 \\
(0.6157)\end{array}$ \\
\hline$G O V \_E F F$ & $\begin{array}{c}0.0653 \\
(0.9452)\end{array}$ & $\begin{array}{c}1.6374 * * * \\
(0.0670)\end{array}$ & $\begin{array}{l}-0.0879 \\
(0.9019)\end{array}$ & $\begin{array}{c}0.6025 \\
(0.5417)\end{array}$ & $\begin{array}{c}0.6668 \\
(0.5161)\end{array}$ & $\begin{array}{l}-0.3563 \\
(0.8550)\end{array}$ & $\begin{array}{c}0.5231 \\
(0.5952)\end{array}$ & $\begin{array}{c}0.8273 \\
(0.4370)\end{array}$ \\
\hline$V O I C E \_A C C$ & $\begin{array}{c}0.7581 \\
(0.6031)\end{array}$ & $\begin{array}{l}-0.6281 \\
(0.6183)\end{array}$ & $\begin{array}{c}-2.4859^{* *} \\
(0.0049)\end{array}$ & $\begin{array}{c}0.9135 \\
(0.5453)\end{array}$ & $\begin{array}{c}0.9047 \\
(0.5575)\end{array}$ & $\begin{array}{c}1.9573 \\
(0.3792)\end{array}$ & $\begin{array}{c}1.0890 \\
(0.4648)\end{array}$ & $\begin{array}{c}0.7295 \\
(0.6323)\end{array}$ \\
\hline CORR_CTRL & $\begin{array}{r}-0.7726 \\
(0.4162) \\
\end{array}$ & $\begin{array}{r}-0.0795 \\
(0.8519) \\
\end{array}$ & $\begin{array}{l}1.6235^{*} \\
(0.0053) \\
\end{array}$ & $\begin{array}{l}-1.5239 \\
(0.1324) \\
\end{array}$ & $\begin{array}{l}-0.6915 \\
(0.4908) \\
\end{array}$ & $\begin{array}{l}-2.5351 \\
(0.1787) \\
\end{array}$ & $\begin{array}{r}-0.8761 \\
(0.3784) \\
\end{array}$ & $\begin{array}{l}-1.0341 \\
(0.3202) \\
\end{array}$ \\
\hline \multicolumn{9}{|l|}{$\begin{array}{r}\text { Economic Control } \\
\text { Variables: }\end{array}$} \\
\hline CAPITAL & $\begin{array}{l}0.3799^{*} \\
(0.0000)\end{array}$ & $\begin{array}{l}0.3861 * \\
(0.0000)\end{array}$ & $\begin{array}{l}0.2396^{*} \\
(0.0000)\end{array}$ & $\begin{array}{l}0.3823 * \\
(0.0000)\end{array}$ & $\begin{array}{l}0.3625^{*} \\
(0.0000)\end{array}$ & $\begin{array}{l}0.1565^{* *} \\
(0.0347)\end{array}$ & $\begin{array}{l}0.3652 * \\
(0.0000)\end{array}$ & $\begin{array}{l}0.3882 * \\
(0.0000)\end{array}$ \\
\hline IMPORTS & $\begin{array}{l}0.0568^{*} \\
(0.0101)\end{array}$ & $\begin{array}{c}0.0130 \\
(0.2922)\end{array}$ & $\begin{array}{c}0.0130 * * \\
(0.0381)\end{array}$ & $\begin{array}{l}0.0095^{*} \\
(0.0065)\end{array}$ & $\begin{array}{l}0.0745^{*} \\
(0.0016)\end{array}$ & $\begin{array}{c}0.0593 \\
(0.1800)\end{array}$ & $\begin{array}{l}0.0685^{*} \\
(0.0019)\end{array}$ & $\begin{array}{c}0.0598^{* *} \\
(0.0105)\end{array}$ \\
\hline$G O V \_E X P$ & $\begin{array}{l}-0.9173^{*} \\
(0.0000)\end{array}$ & $\begin{array}{l}-0.5462^{*} \\
(0.0000)\end{array}$ & $\begin{array}{l}-0.1324^{*} \\
(0.0069)\end{array}$ & $\begin{array}{l}-0.9255^{*} \\
(0.0000)\end{array}$ & $\begin{array}{c}-0.8529^{*} \\
(0.0000)\end{array}$ & $\begin{array}{l}-1.4558^{*} \\
(0.0000)\end{array}$ & $\begin{array}{l}-0.8980^{*} \\
(0.0000)\end{array}$ & $\begin{array}{c}-0.7567^{*} \\
(0.0000)\end{array}$ \\
\hline SPEND & $\begin{array}{c}0.1906 \\
(0.8317)\end{array}$ & $\begin{array}{c}-0.4786^{* * *} \\
(0.0488)\end{array}$ & $\begin{array}{c}-0.1939 * * * \\
(0.0701)\end{array}$ & $\begin{array}{r}-0.5457 \\
(0.5414)\end{array}$ & $\begin{array}{r}-0.1936 \\
(0.8401)\end{array}$ & $\begin{array}{c}0.4302 \\
(0.8161)\end{array}$ & $\begin{array}{c}-0.5611 \\
(0.5280)\end{array}$ & $\begin{array}{c}0.0210 \\
(0.9823)\end{array}$ \\
\hline \multirow{3}{*}{$\begin{array}{r}\text { Observations } \\
\text { Adjusted R-Squared } \\
\text { Prob Hausman Test }\end{array}$} & 560 & 560 & 528 & 528 & 514 & 192 & 546 & 496 \\
\hline & 0.4330 & 0.3489 & 0.2645 & 0.4112 & 0.4282 & 0.4034 & 0.4322 & 0.4228 \\
\hline & 0.0000 & 0.0000 & 0.9597 & 0.0000 & 0.0615 & 0.0069 & 0.0004 & 0.0000 \\
\hline F-statistic & 10.08559 & 7.363138 & 15.55798 & 9.214568 & 9.539519 & 6.381598 & 9.826962 & 8.555756 \\
\hline $\operatorname{Prob}(F$-statistic) & 0.000000 & 0.000000 & 0.000000 & 0.000000 & 0.000000 & 0.000000 & 0.000000 & 0.000000 \\
\hline
\end{tabular}

Source: Authors' own processing; * Level of significance 1\%; ** Level of significance 5\%; *** Level of significance $10 \%$; The brackets enclose the statistical probabilities of the estimated coefficients.

Within model 3, Taxes on personal income and capital gains of individuals are not significant and do not impact the dependent variable. The estimations of the other variables within the model show negative effects on economic growth due to the influence of factors such as Voice and accountability (significance - no effects: model 7; with effects: model 3). Furthermore, the public governance indicators provide an overview of a country's political environment, which is influenced by various factors such as corruption and terrorism. The public governance indicators such as the Regulatory quality and Control of corruption influence economic

DOI: 10.24818/18423264/55.2.21.14 
Does Fiscal Policy Influence the Economic Growth? - Evidence from OECD Countries

growth in a positive manner and highlight a sensitivity of citizens towards the changing aspects arising in the political environment as well as in the legal and regulatory framework of a country. More specifically, the positive perception of the citizens is quantified by an increase in the measurement coefficients of both indicators that increase the economic growth rate by 1.5 , respectively 1.6 percent.

Moreover, similar to the estimation of model 1 , an increase in the volume of imports in model 3 leads to an increase in the amount of the GDP. Additionally, among the variables with negative influences there is the estimated coefficient of the Rule of law indicator (RULE_LAW), which causes an economic decrease by 3.27 (no effects) and 2.3 percent (random effects).Within the model 4, we estimated the impact of the Taxes on corporate profits upon the economic growth, however the results showed that this fiscal variable has insignificant impact no matter the application of effects or non-effects.

Nonetheless, Social security contributions are based on the funding of expenses incurred by specific public institutions from which the taxpayers would be able to benefit in certain situations such as unemployment benefits, public pensions or health services. The coefficient related to the social security contribution is estimated in model 5 with fixed and without effects, thus its influence on the dependent variable causes an economic decrease of $0.16 \%$ and $0.34 \%$ because that tax burden resulting from the obligation to pay the social security contributions affects the gross income of taxpayers. The results further indicated negative effects exerted by Government expenditure and the Rule of law and positive effects exerted by Imports, Gross capital formation and and the Tax wedge.

The sixth econometric model comprises the Payroll taxes as independent fiscal variable and according to the results it is not statistically significant due to the low amount of observations and to the fact that payroll taxes are not collected in most of the OECD countries. On the other hand, the estimated coefficient of Political Stability and Absence of Violence/Terrorism is significant without effect and exerts negative impact upon the economic growth.Model 7 includes the Taxes on property as fiscal variable, thus in both estimations it proves to have positive effect on economic growth because ownership and investment in real estate and properties give owners the opportunity to support other various economic activities. The positive results are also supported by the influences of Gross capital formation, Imports, the tax burden (the higher the tax burden, the longer the economic growth is sustained) and public governance indicators such as the Regulatory Quality, Political Stability and Absence of Violence/Terrorism, the quality of public services and the perception of corruption control. Moreover, the eighth model of the empirical study presents a robust analysis of the effects of all fiscal variables used in the research, furthermore the estimated results highlights that Taxes on goods and services, Payroll taxes and Property taxes have positive effects on economic growth while the Social security contributions have negative effects.

DOI: 10.24818/18423264/55.2.21.14 
Table 5 summarizes the outcomes by employing the Least Squares Method. Therefore, taxes on personal income, Taxes on corporate profits and Payroll taxes are not significant in the estimation with the least squares method. However, the tax variables with positive impact include Taxes on goods and services, Total tax revenues and Property taxes; such positive effects could come as a result of the investments made and the support in productive economic activities. In other words, Social security contributions have negative impact on economic growth considering this as a consequence of the tax burden upon the taxpayers' gross income.

Table 5. Estimated results showing the effects of the fiscal variables upon economic growth - Least Squares Method

\begin{tabular}{|c|c|c|c|c|}
\hline Model & Fiscal Variable & Significant & Effects & Impact \\
\hline \multirow{2}{*}{1} & \multirow{2}{*}{ Taxes on Goods and Services } & \multirow[t]{2}{*}{ YES } & NO EFFECTS & \multirow[t]{2}{*}{ POSITIVE } \\
\hline & & & FIXED EFFECTS & \\
\hline 2 & Total Fiscal Revenues & YES & FIXED EFFECTS & POSITIVE \\
\hline 3 & Taxes on Personal Income & & NOT SIGNIFICANT & \\
\hline 4 & Taxes on Corporate Profits & & NOT SIGNIFICANT & \\
\hline \multirow{2}{*}{5} & \multirow{2}{*}{ Social Security Contributions } & YES & NO EFFECTS & \multirow[t]{2}{*}{ NEGATIVE } \\
\hline & & & FIXED EFFECTS & \\
\hline 6 & Payroll Taxes & & NOT SIGNIFICANT & \\
\hline \multirow{2}{*}{7} & \multirow{2}{*}{ Taxes on Property } & YES & NO EFFECTS & \multirow[t]{2}{*}{ POSITIVE } \\
\hline & & & FIXED EFFECTS & \\
\hline \multirow{8}{*}{8} & \multirow{2}{*}{ Taxes on Goods and Services } & YES & NO EFFECTS & \multirow[t]{2}{*}{ POSITIVE } \\
\hline & & & FIXED EFFECTS & \\
\hline & Taxes on Personal Income & & NOT SIGNIFICANT & \\
\hline & Taxes on Corporate Profits & & NOT SIGNIFICANT & \\
\hline & Social Security Contributions & YES & FIXED EFFECTS & NEGATIVE \\
\hline & Payroll Taxes & & NOT SIGNIFICANT & \\
\hline & \multirow{2}{*}{ Taxes on property } & YES & NO EFFECTS & \multirow[t]{2}{*}{ POSITIVE } \\
\hline & & & FIXED EFECTS & \\
\hline
\end{tabular}

Source: Author's own processing.

\subsection{Robustness Checks}

Further to the analysis, Table 6 highlights the results of the estimation with the Generalized Method of Moments - GMM. The generalized method of moments is effective because it improves the assessment of the estimators and is simple to implement. Establishing as instrumental variables the global governance indicators, we determined the following results:Taxes on goods and services have positive impact on the economic growth rate, the estimated coefficients are statistically significant in both GMM models as it follows: within model 1, an increase by one percentage point of Taxes on goods and services would lead to an economic growth of $0.42 \%$; on the other hand, in model 8 the economy would grow by $0.91 \%$; Total tax revenues are directly and positively correlated with the economic growth rate, with a coefficient of 0.7046 that is statistically significant; Personal income taxes also have positive influence on the dependent variable with an estimated coefficient of 0.5747; Significant variables with negative impact are those reported by Taxes on corporate profits and Social security contributions with estimated coefficients of -1.7284 , respectively -0.6975 ; Payroll taxes and Property taxes are statistically insignificant. 
Does Fiscal Policy Influence the Economic Growth? - Evidence from OECD Countries

\begin{tabular}{|c|c|c|c|c|c|c|c|c|}
\hline \multicolumn{9}{|c|}{ Table 6. Generalized Method of Moments (GMM) estimation results } \\
\hline & \multicolumn{8}{|c|}{$G M M$} \\
\hline $\begin{array}{r}\text { Dependent Variable: } \\
\text { GDP_GRATE }\end{array}$ & (1) & (2) & (3) & (4) & (5) & (6) & (7) & (8) \\
\hline \multirow{2}{*}{\multicolumn{9}{|c|}{ Independent Variables: }} \\
\hline & $-0.2707^{*}$ & $-0.1359^{* *}$ & $-0.0676^{* *}$ & $-0.3193^{*}$ & $-0.2455^{*}$ & $-0.3633^{* *}$ & $-0.2832 *$ & $-0.3838 *$ \\
\hline \multirow{3}{*}{ GS_TAX } & $(0.0000)$ & $(0.0120)$ & $(0.0500)$ & $(0.0000)$ & $(0.0000)$ & $(0.0431)$ & $(0.0000)$ & $(0.0000)$ \\
\hline & $0.4264^{*}$ & & & & & & & $0.9144 *$ \\
\hline & $(0.0000)$ & & & & & & & $(0.0026)$ \\
\hline TOT_TAX & & $\begin{array}{l}0.7046^{*} \\
(0.0001)\end{array}$ & & & & & & \\
\hline INC_TAX & & & $0.5747 * *$ & & & & & 1.8849 \\
\hline PROF_TAX & & & & $-1.7284 *$ & & & & -0.1766 \\
\hline SOC_TAX & & & & & $\begin{array}{c}-0.6975 * * \\
(0.0290)\end{array}$ & & & $\begin{array}{c}0.6320 \\
(0.6499)\end{array}$ \\
\hline$S A L \_T A X$ & & & & & & $\begin{array}{l}-2.6838 \\
(0.8072)\end{array}$ & & $\begin{array}{c}6.8209 \\
(0.4663)\end{array}$ \\
\hline$O W N \_T A X$ & & & & & & & 0.1009 & 2.3336 \\
\hline$T A X \_W E D G E$ & $\begin{array}{c}1.0825 \\
(0.0000)\end{array}$ & $\begin{array}{l}-0.0417 \\
(0.7549)\end{array}$ & $\begin{array}{c}0.2574 * * * \\
(0.0838)\end{array}$ & $\begin{array}{l}0.8285^{*} \\
(0.0000)\end{array}$ & $\begin{array}{l}1.0244 * \\
(0.0000)\end{array}$ & $\begin{array}{l}1.6021^{* * *} \\
(0.0106)\end{array}$ & $\begin{array}{l}0.6523^{*} \\
(0.0000)\end{array}$ & $\begin{array}{c}(0.2110) \\
0.7115 \\
(0.2039)\end{array}$ \\
\hline CAPITAL & $\begin{array}{l}0.3846^{*} \\
(0.0000)\end{array}$ & $\begin{array}{l}0.3786^{*} \\
(0.0000)\end{array}$ & $\begin{array}{l}0.2840^{*} \\
(0.0000)\end{array}$ & $\begin{array}{l}0.3355^{*} \\
(0.0004)\end{array}$ & $\begin{array}{l}0.2542^{*} \\
(0.0000)\end{array}$ & $\begin{array}{c}0.6817 \\
(0.2968)\end{array}$ & $\begin{array}{l}0.2383^{*} \\
(0.0000)\end{array}$ & $\begin{array}{c}0.3428 \\
(0.1568)\end{array}$ \\
\hline IMPORTS & $\begin{array}{c}0.0666^{* * * * *} \\
(0.0694)\end{array}$ & $\begin{array}{l}0.1744^{*} \\
(0.0056)\end{array}$ & $\begin{array}{l}0.0666^{*} \\
(0.0098)\end{array}$ & $\begin{array}{l}0.0885^{*} \\
(0.0007)\end{array}$ & $0.0426 * *$ & $\begin{array}{r}-0.2663 \\
(0.2119)\end{array}$ & $\begin{array}{l}0.1545^{*} \\
(0.0000)\end{array}$ & 0.1242 \\
\hline \multirow[t]{2}{*}{$G O V_{-} E X P$} & $-2.5417^{*}$ & $-11.6366^{*}$ & $-1.3831^{*}$ & $-3.5063^{*}$ & $\begin{array}{l}(0.0419) \\
-2.7968^{*}\end{array}$ & $-2.4853 * * *$ & $\begin{array}{l}(0.0060) \\
-3.0681^{*}\end{array}$ & $-2.6334 *$ \\
\hline & $(0.0000)$ & $(0.0000)$ & $(0.0000)$ & $(0.0000)$ & $(0.0000)$ & $(0.0526)$ & $(0.0000)$ & $(0.0069)$ \\
\hline \multirow[t]{2}{*}{ SPEND } & 1.0968 & -0.7510 & -0.3015 & -0.6112 & 0.6710 & 8.1386 & -1.7818 & $-2.3074 *$ \\
\hline & $(0.2671)$ & $(0.6851)$ & $(0.7379)$ & $(0.6400)$ & $(0.6498)$ & $\begin{array}{l}0.1500 \\
(0.3929)\end{array}$ & $(0.1111)$ & $(0.0069)$ \\
\hline \multirow[t]{2}{*}{ TAX_FREE } & $-0.1012 * *$ & $-0.2732 *$ & -0.1035 & -0.0050 & $-0.0987 * *$ & -0.1077 & $-0.1534 * *$ & 0.1087 \\
\hline & $(0.0464)$ & $(0.0000)$ & $(0.1105)$ & $(0.9428)$ & $(0.0205)$ & $(0.3991)$ & $(0.0348)$ & $(0.5693)$ \\
\hline Observations & 490 & 489 & 461 & 462 & 449 & 168 & 477 & 434 \\
\hline J-statistic & 28.78782 & 32.28495 & 27.82711 & 29.24647 & 30.05702 & 2.365513 & 30.39427 & 19.22225 \\
\hline $\operatorname{Prob}(J$-statistic $)$ & 0.371263 & 0.221695 & 0.315874 & 0.253744 & 0.222161 & 0.668868 & 0.296732 & 0.378259 \\
\hline Instrumental Variables & & RULE & 然 & (5) & $O V E F F, C$ & CTRL, VOI & $A C C$ & \\
\hline
\end{tabular}

significance $10 \%$; The brackets enclose the statistical probabilities of the estimated coefficients.

Furthermore, Table 7 presents the significance of the estimated fiscal variables by applying the GMM method.

Table 7. Results of the estimation of the fiscal variables by applying the Generalised Method of Moments (GMM)

\begin{tabular}{cccc}
\hline Model & Fiscal Variable & Significant & Impact \\
\hline $\mathbf{1}$ & Taxes on goods and services & YES & POSITIVE \\
\hline $\mathbf{2}$ & Total tax revenues & YES & POSITIVE \\
\hline $\mathbf{3}$ & Taxes on personal income & YES & POSITIVE \\
\hline $\mathbf{4}$ & Taxes on corporate profits & YES & NEGATIVE \\
\hline $\mathbf{6}$ & Social security contributions & YES & NEGATIVE \\
\hline $\mathbf{7}$ & Payroll taxes & NOT SIGNIFICANT \\
\hline
\end{tabular}

Source: Authors' own processing.

The following economic control variables influence the economic growth rate: Gross fixed capital formation, Imports, Government expenditure and Private household consumption. Thus: Gross fixed capital formation (CAPITAL): positive impact underlined in all the models estimated with the OLS method and only in models 1-5 and 7 with the GMM method; the results emphasize a higher degree of economic development among the OECD countries also because by increasing the GDP per capita and the purchase power, direct investments and production would increase the demand; Imports (IMPORTS): positive impact in all models, except for model 2 where imports are not significant for the OLS method and significant

DOI: 10.24818/18423264/55.2.21.14 
in models 1-5 and 7 for the GMM method; the high volume of imports is explained by the actions taken in order to encourage growth and productivity in the economy; Government expenditure (GOV_EXP): negative impact for all models estimated by both methods, fact which underlines their unproductive use; Private household consumption (SPEND): negative impact in both estimations except for models 1 and 8 for OLS method and models 1 - 7 for GMM method; more specifically, rising consumption implies economic decline when consumption is not supported by efficient production and sustainable demand. Moreover, private household consumption should involve a reasonable allocation of income in order to create added value and avoid indebtedness.

Finally, the results of the estimation of the public governance indicators by applying the least squares method are statistically significant to a lesser extent, compared to the other results concluded as follows: Tax Freedom (TAX_FREE): this indicator measures the perception of the tax burden; the results determined negative effects upon economic growth in all models, except for models 5 and 6 (for which the estimated coefficient is not significant); therefore a high tax burden leads to economic decrease because production processes would no longer be encouraged and demand will decline;

Rule of Law (RULE_LAW): negative impact; this variable is significant in models $3,4,5,7$ and 8 ; the results could be explained by the subjective nature of this indicator, the complementarities between the public institutions due to the legislative frameworks in the analyzed countries and also by the risk of expropriations and the level of violence and terrorism (Haggard and Tiede, 2011);

Regulatory Quality (REG_QLTY): is significant with positive impact in models 2,4 and 7 as a result of the effective management of the governments in what regards the implementation of policies and regulations; Political Stability and Absence of Violence/Terrorism (POL_STAB): negative impact and significant only in model 6 (no effects, OLS method);Government effectiveness (GOV_EFF): positive impact, significant only in model 8 (no effects, OLS method);Voice and Accountability (VOICE_ACC): this indicator is significant with negative impact only in models 3 (no effects, OLS) and 7 (fixed effects, OLS method);Control of Corruption (CORR_CTRL): positive impact and significant in models 2, 3, 4 and 7 (OLS method).

\section{Conclusions}

The results of the econometric analysis of the economic impact of Taxes on goods and services on economic growth rate in OECD countries demonstrate a significant link between fiscal policy and GDP growth. According to the econometrical estimations of the fiscal variables, we remarked that the impact remains the same regardless of the method applied. Moreover, the variables with positive impact results are Taxes on goods and services; Total tax revenues, Taxes on personal income and Property taxes. Meantime, Taxes on corporate profits and Social security contributions have negative impact while Payroll taxes are not

DOI: $10.24818 / 18423264 / 55.2 .21 .14$ 
Does Fiscal Policy Influence the Economic Growth? - Evidence from OECD Countries

significant. An increased level of taxation can negatively affect production efficiency because it has significant effects on income distribution and social welfare. Global governance indicators highlight the role of governments in fiscal policies while corruption plays an important role in increasing the income inequality levels and economic decline (Bayar and Aytemiz, 2019, Haggard and Tiede, 2011). The results also indicated negative influences of government expenditure on economic growth (Jones et al., 1993, Barro, 1990) because the expenditure is not productive or efficiently managed. Moreover, indirect taxes have positive impact on economic growth because they lead to lower consumption and reduce the negative effects of inefficient fiscal policies (Helbling, 2010). According to the reference literature (Arnold et al., 2011, Gemmell et al., 2011), the results show that in order to maintain an efficient and sustainable economic growth, it is necessary for governments to adopt such fiscal policies that aim to reduce poverty and inequality of chances.

\section{REFERENCES}

[1] Aliani, K., Mhamid, I. \& Rossi, M. (2017), Does CEO Overconfidence Influence Tax Planning? Evidence from Tunisian Context. International Journal of Managerial and Financial Accounting, 8, 197-208;

[2] Arin, K. P. \&Koray, F. (2006), Are Some Taxes Different than Others? An Empirical Investigation of the Effects of Tax Policy in Canada. Empirical Economics, 31, 183-193;

[3] Armeanu, D. S., Vintila, G. \& Gherghina, S. C. (2018),Empirical Study towards the Drivers of Sustainable Economic Growth in EU-28 Countries. Sustainability, 10; [4] Arnold, J. (2008),Do Tax Structures Affect Aggregate Economic Growth? Empirical Evidence from a Panel of OECD Countries In: OECD (ed.). Paris: $O E C D$ Publishing;

[5] Arnold, J. M., Brys, B., Heady, C., Johansson, A., Schwellnus, C. \&Vartia, L. (2011),Tax Policy for Economic Recovery and Growth. Economic Journal, 121, F59F80;

[6] Barro, R. J. (1990), Government Spending in A Simple-Model of Endogenous Growth. Journal of political economy, 98, s103-s125;

[7] Bayar, Y. \& Aytemiz, L. (2019), The Misery Index, Corruption and Income Inequality in Latin American Countries: A Panel Cointegration and Causality

Analysis. Scientific annals of economics and business, 66, 309-319;

[8] Capolupo, R. (2000), Output Taxation, Human Capital and Growth. Manchester school, 68, 166-183;

[9] Carboni, O. A. (2017),The Effect of Public Support on Investment and R\&D: An Empirical Evaluation on European Manufacturing Firms. Technological forecasting and social change, 117, 282-295;

[10] Decoster, A., Loughrey, J., O'Donoghue, C. \& Verwerft, D. (2010),How

Regressive Are Indirect Taxes? A Microsimulation Analysis for Five European

Countries. Journal of policy analysis and management, 29, 326-350;

DOI: $10.24818 / 18423264 / 55.2 .21 .14$ 
GeorgetaVintilă, Ștefan Cristian Gherghina, Ștefania Cosmina Chiricu

[11] Ekins, P., Pollitt, H., Summerton, O. \& Chewpreecha, U. (2012),Increasing Carbon and Material Productivity through Environmental Tax Reform. Energy policy, 42, 365-376;

[12] Fetai, B. T., Mustafi, B. F. \&Fetai, A. B. (2017),An Empirical Analysis of the Determinants of Economic Growth in the Western Balkans. Scientific annals of economics and business, 64, 245-254;

[13] Gemmell, N., Kneller, R. \&Sanz, I. (2011),The Timing and Persistence of Fiscal Policy Impacts on Growth: Evidence from OECD Countries. Economic journal, 121, f33-f58;

[14] Gherghina, S. C., Onofrei, M., Vintila, G. \&Armeanu, D. S. (2018),Empirical Evidence from Eu-28 Countries on Resilient Transport Infrastructure Systems and Sustainable Economic Growth. Sustainability, 10;

[15] Haggard, S. \&Tiede, L. (2011), The Rule of Law and Economic Growth:

Where Are We? World development, 39, 673-685;

[16] Helbling, T. (2010),Back to Basics. What Are Externalities? What Happens when Prices Do Not Fully Capture Costs. Finance \&Development, 47, 48-49;

[17] Jones, L. E., Manuelli, R. E. \& Rossi, P. E. (1993), Optimal Taxation in Models of Endogenous Growth. Journal of political economy, 101, 485-517;

[18] Kim, S., Lim, H. \&Park, D. (2007),Could Imports Be Beneficial for Economic Growth? Some Evidence from Republic of Korea. Metro manila, Philippines: Asian development bank;

[19] Lucas, R. E. (1988), On the Mechanics of Economic-Development. Journal of monetary economics, 22, 3-42;

[20] Mdanat, M. F., Shotar, M., Samawi, G., Mulot, J., Arabiyat, T. S. \&Alzyadat, M. A. (2018),Tax Structure and Economic Growth in Jordan, 1980-2015. Euromed journal of business, 13, 102-127;

[21] Munir, K. \&Sultan, M. (2018), Are Some Taxes Better for Growth in Pakistan?

A Time Series Analysis. International journal of social economics, 45, 1439-1452;

[22] Rao, B. B. (2010), Time-Series Econometrics of Growth-Models: A Guide for

Applied Economists. Applied economics, 42, 73-86;

[23] Reed, W. R. (2008), The Robust Relationship between Taxes and Us State

Income Growth. National tax journal, 61, 57-80;

[24] Sturm, J.-E., Kuper, G. H. \&Haan, J. D. (1998), Modelling Government Investment and Economic Growth on a Macro Level: A Review .In: Brakman, S., [30] Ees, H. V. \& Kuipers, S. K. (eds.)Market behaviour and macroeconomic modelling. London: palgravemacmillan;

[25] Wang, W. K., Lu, W. M. \&Wang, S. W. (2014), The Impact of Environmental Expenditures on Performance in the US Chemical Industry. Journal of cleaner production, 64, 447-456. 